\title{
IMPACT OF SERVICE QUALITY ON SATISFACTION AND \\ LOYALTY OF TOURISTS IN RURAL TOURISM OF ŠUMADIJA AND WESTERN SERBIA
}

\author{
Goran Perićl, Sandra Dramićanin ${ }^{2}$, Marko Gašić ${ }^{3}$ \\ *Corresponding author E-mail: goran.peric@vpskp.edu.rs
}

A R T I C LE IN F O

Original Article

Received: 06 March 2020

Accepted: 19 November 2020

doi:10.5937/ekoPolj2004071P

UDC 338.518:338.48-44(1-22) (497.11 Šumadija)

Keywords:

rural tourism, quality, satisfaction, loyalty, Šumadija and Western Serbia

JEL: Z32, Z33, M31

\begin{abstract}
A B S T R A C T
The issue of rural tourism service quality does not retain a sufficiently important place in the existing domestic and foreign literature. The purpose of this research in service quality, which is an important initiator of tourist satisfaction and loyalty in rural tourism. The survey was conducted at the beginning of 2020 using a questionnairebased survey method to 299 respondents. With the purpose of checking the impact of the service quality on the satisfaction and loyalty of tourists in rural tourism of Šumadija and Western Serbia, an analysis was performed using SEM - Structural Equation Modeling. The survey results point there is a direct correlation between service quality and satisfaction, and as well between loyalty and satisfaction. Between service quality and loyalty there is not a direct link, but there is a large indirect effect by satisfaction. The implications of this research, limitations and future research recommendations for are outlined.
\end{abstract}

(C) 2020 EA. All rights reserved.

\section{Introduction}

For a long time, tourism has been defined as economic catalyst for rural-economic development and renewal of rural areas (Sharpley, 2002). Each local rural community or wider rural area has certain characteristics that make it more or less capable of adapting to the constantly changing social conditions. Local potentials for the development of rural tourism is directly determined by social vitality, which also determines the contribution of rural tourism to the development of local community. Recognizing

1 Goran Perić, MSc, Lecturer, Academy of Professional Studies South Serbia, Department of Business Studies Blace, Kralja Petra I, No. 1, Blace, Serbia, Phone: +381 652912 980, E-mail: goran.peric@vpskp.edu.rs, ORCID ID (http://orcid.org/0000-0001-7954-7663)

2 Sandra Dramićanin, MSc, PhD student at Faculty of Hotel Management and Tourism in Vrnjačka Banja, Vojvođanska bb, Vrnjačka Banja, Serbia, Phone: +381 641566 582, E-mail: sandradramicanin@hotmail.com, ORCID ID (https://orcid.org/0000-0001-6533-2071)

3 Marko Gašić, PhD, Professor, Academy of Professional Studies South Serbia, Department of Business Studies Blace, Kralja Petra I, no. 1, Blace, Serbia, Phone: +381 637629075 , E-mail: gasicmarko@yahoo.com, ORCID ID (https://orcid.org/0000-0002-5256-4794) 
that rural space is much more than a place where agricultural production takes place, rural tourism is gaining new impetus (Irz et al., 2001). Rural tourism, as a significant segment of multifunctional agriculture, refers the fastest rural economy diversification, in particular by emphasizing the output of agri-food products in tourists quality nutrition (Cvijanovic \& Mihailovic, 2016).

In last few years, rural tourism has been increasing owing to improved demand in the tourism market and measures implemented by countries to develop rural areas (Novakovic \& Peric, 2018). Rural tourism is a key in the sustainable development of rural environments. Rural tourism has ability to create stable employment and the stability of tourist activity condition an acceptable level of profits (Martinez et al., 2019). It is a repercussion of the increasing urban population needs for recreational use of different, rural environment (Gašić, 2016). According to unofficial data and some estimates, about $25 \%$ of tourists in the world annually are keen for rural tourism (UNWTO, 2011; Radović, 2013). In the future this trend will continue, the research carried out by the World Tourism Organization (Gašić et al., 2014) supports this.

The regions of Šumadija and Western Serbia have great potential for rural tourism development. The region of Sumadija and Western Serbia is the largest in terms of surface area. Also, that is the most visited region in Serbia. Quality has become one of the most consequential elements in the business of rural tourism households (Gašić et al., 2015b), and thus has attracted our attention for research, bearing in mind that research of rural tourism quality is rare (Loureiro \& González, 2008 ). This paper examines the impact of service quality on the satisfaction and loyalty of tourists in the rural tourism of Šmadija and Western Serbia.

\section{Literature review}

Rural tourism, as the broadest term, includes all types of tourism and services that take place in rural environments (Roberts \& Hall, 2008). Rural space is considered to be areas in which the present or recent past has been dominated by land use, most often through agriculture, dominated by small settlements with a strong connection between built and natural environment and which nurture a lifestyle built on the basis of environmental maintenance (Cizler, 2013). Rural tourism encompasses all types of tourism in rural spaces (Demonja \& Ružić, 2010). Rural tourism represents tourism that happens in the countryside (Lane, 1994). Rural tourism includes a wide range of activities, services and additional facilities to attract tourists in order to generate additional income (Milićević et al., 2015).

Rural areas are coming into the spotlight now (Milićević et al., 2015). Growth of rural areas is an essence for valoriation of sector of agriculture (Perić et al., 2020). In all developed countries rural tourism has potential for growing (Loureiro \& González, 2008; Lee \& Kim, 2009; Koster \& Lemelin, 2009; Chuang, 2010). In order to revitalize the villages, inculcate money and offer different experience, rural and eco-tourism appeared (Blažević et al., 2018). For rural areas that have been or are still economically 
underdeveloped, tourism plays an consequential part in evolvent (Podovac et al., 2019; Jurdana \& Frleta, 2012). Consequently, the rural tourism development meliorate activity of the population of rural sector and economic position (Mandarić et al., 2017).

Rural tourism is often considered a good option for rural development and poverty reduction (Xue \& Kerstetter, 2019). A sufficiently solid basis are households, the conservation, natural resources and their attractiveness and richness (Gašić et al., 2015a; Pavlović, 2016; Novaković \& Perić, 2018). Even so, rural tourism has not been amply developing the opportunities it has. According to statistical data, the region of Šmadija and western Serbia is one of the five largest regions in terms of population and area, and that is the most frequented by tourists and generates $17.18 \%$ of arrivals and $42.1 \%$ of overnights in terms of total tourist traffic in the Republic of Serbia (Statistical Yearbook, 2019). Rural tourism has been considered as a means of achieving economic and social development and regeneration that can benefit to local people (Fang, 2020).

In Serbia rural tourism is associated with rural environments that represent the basic receptive areas of rural tourism, while the main emitting areas of rural tourism are precisely large urban agglomerations and highly urbanized environments. Through rural tourism of Serbia, quality products and services of various activities are presented (catering, rural, food processing, entrepreneurial, cultural-artistic, sports-recreational offer) (Simonović \& Ćurčić, 2020). Rural tourism of the Republic of Serbia relies primarily on domestic demand from urban areas, so that its more intensive development could contribute to the transfer of income from economically developed urban regions to underdeveloped rural areas. Thus, tourism would contribute to faster economic development of rural areas, which would reduce the existing gap in the development of rural and urban areas (Vuković, 2017). The development of rural tourism is based on enriching the supply of family rural households, primarily through the establishment of local and regional human-created attractions such as wine cellars, recreational facilities, viewpoints, theme parks and the like. Priority is given to thematizing supply by grouping rural households according to different topics (family, organic farming, riding programs, cyclotourism) (Dašić et al., 2020).

The delivery of high quality services to customers is recognized as a essence factor who has an effect on the company performance (Vujić et al., 2019). Consumer satisfaction, loyalty and service quality and their connection are among the most popular topics for researchers (Zabkar et al., 2010), while rare research has been applied in rural tourism (Loureiro \& González, 2008). Tourism as a service industry requires an understanding of the needs, attitudes, expectations and preferences of service users (Topalović \& Marinković, 2020). Rural tourist destinations are increasingly dependent on quality. Quality has become the most important element of rural tourist households (Gašić et al., 2015b). Sercice quality in rural tourism is created by the processes of service delivery (friendliness, courtesy, efficiency, reliability, staff competence) and outcomes of services (accommodation, food, leisure facilities) (Žabkar et al., 2010). Service quality in rural tourism is conceived as evaluation of performance ( $\mathrm{Su}$ et al., 2016). 
It is not easy to define and determine service quality, unlike product quality, primarily because of features such as intangibility, heterogeneity, inseparability, and sustainability (Lee et al., 2011). Service quality has two dimension (technical and functional quality), and Grönroos (1984) was the first to define them. The difference between consumer expectations and the perception of service delivered is a service quality (Parasuraman et al., 1985). Those authors have envolved a as SERVQUAL (service quality measurement model), within which they identified five dimensions of service quality: tangibility, reliability, accountability, safety and empathy (Parasuraman et al., 1988). The SERVQUAL model makes it possible to crossbreed consumers' perceptions with their expectations and thus to distinguish between the expected and the delivered service. Cronin and Taylor were criticized SERVQUAL model (1992, 1994), so they developed the SERVPERF model. Those authors did not attach significance to expectations. Accordingly, Lourerio (2006) developed a RURALQUAL model. This model is used in measurement of service quality in rural tourism, and it identifies six dimensions of rural tourism service quality: complementary benefits, core benefits, professionalism, reservation rural and cultural environment and tangibility (Loureiro \& Kastenholz, 2011; Loureiro 2012). By this model service quality is a multidimensional construct (Maestro et al., 2007; Grubor \& Milićević, 2019).

Satisfaction of toursits can be understood as an assessment of the customer experience of the services offered, wherein for the satisfaction of tourists it is necessary that the service be rated at least as expectedly good (Singh, 1991). When the customer uses the service and liken the experience with the expected one, customer obtain satisfaction/ dissatisfaction as a result (Heung \& Cheng, 2000). Consumer satisfaction is a replication that can be emotional or cognitive, with a exacting focus, and associated with a particular moment (before and after consuming the service) (Giese \& Cote, 2000). Thus, in tourism, tourists' satisfaction rely on their experience and their observation of provided service quality (Perić et al., 2018).

Loyalty is the prospect that consumers will use a certain type of brand in the coming period, regardless of the market opportunities and efforts of competitors offering the same or similar products and services (Veljković \& Djordjevic, 2010). According to Pike (2009), the highest level of loyalty to a destination is manifested by the plan of tourists to see destination, stay in destination, come again, as well as making recommendations to their friends to visit the destination. Image and quality of destination are an essential element for the loyalty and repetition of tourists' visits to the destination, as confirmed by numerous previous studies (Hosany et al., 2006; Chen \& Tsai, 2007; Bigovic, 2016).

\section{Research Hypotheses and Model Construction}

Chen and Tsai (2007) state that quality, as an assessment of a standard related to the process of consumption or consumption of services, and in relation to experience gained, is recognized as a predictor of satisfaction. Numerous previous studies confirm this link (Bigovic, 2016; Zabkar et al., 2010; Hi \& Song, 2009; Hu et al., 2009; Nowacki, 2009; Loureiro \& González, 2008) and it is possible to find that perceived quality has a 
positive impact on tourists' satisfaction. Accordingly, the first hypothesis is formulated: $\mathrm{H}_{1}$ Rural tourism service quality has a positive impact on tourists' satisfaction.

It has been theoretically observed and empirically ratified that service quality has a positive impact on loyalty, which is manifested through repurchase, that is, with the intention of conducting positive word-of-mouth propaganda (Chi et al., 2020; Bigović, 2016; Casidy, 2014; Žabkar et al., 2010; Hi \& Song, 2009; Loureiro \& González, 2008; Hennessey et al., 2007; Tsiotsou, 2006; Petrick, 2004). Consequently, we formulate a second hypothesis, which reads: $\mathrm{H}_{2}$ Rural tourism service quality has a positive impact on tourists' loyalty.

Satisfaction is the overall emotional response of varying intensity and limited duration and represents the level of overall satisfaction that results in satisfying desires, expectations and needs (Chen \& Tsai, 2007; Giese \& Cote, 2000). Wang and Hsu (2010) state that it is generally accepted that loyalty is directly conditioned by satisfaction as confirmed by numerous previous studies (Bigović, 2016; Chen \& Kao, 2010; Žabkar et al., 2010; Loureiro \& González, 2008; Chen \& Tsai , 2007; Kozak \& Beaman, 2006). In accordance with the above, we formulate a hypothesis that reads: $\mathrm{H}_{3}$ Satisfaction significantly affects the loyalty of tourists in rural tourism.

The relevant theoretical and empirical research concepts were base for research model (Figure 1) that illustrates the relationship among quality, satisfaction and loyalty of tourists in rural tourism in Šumadija and Western Serbia.

Figure 1. Research model

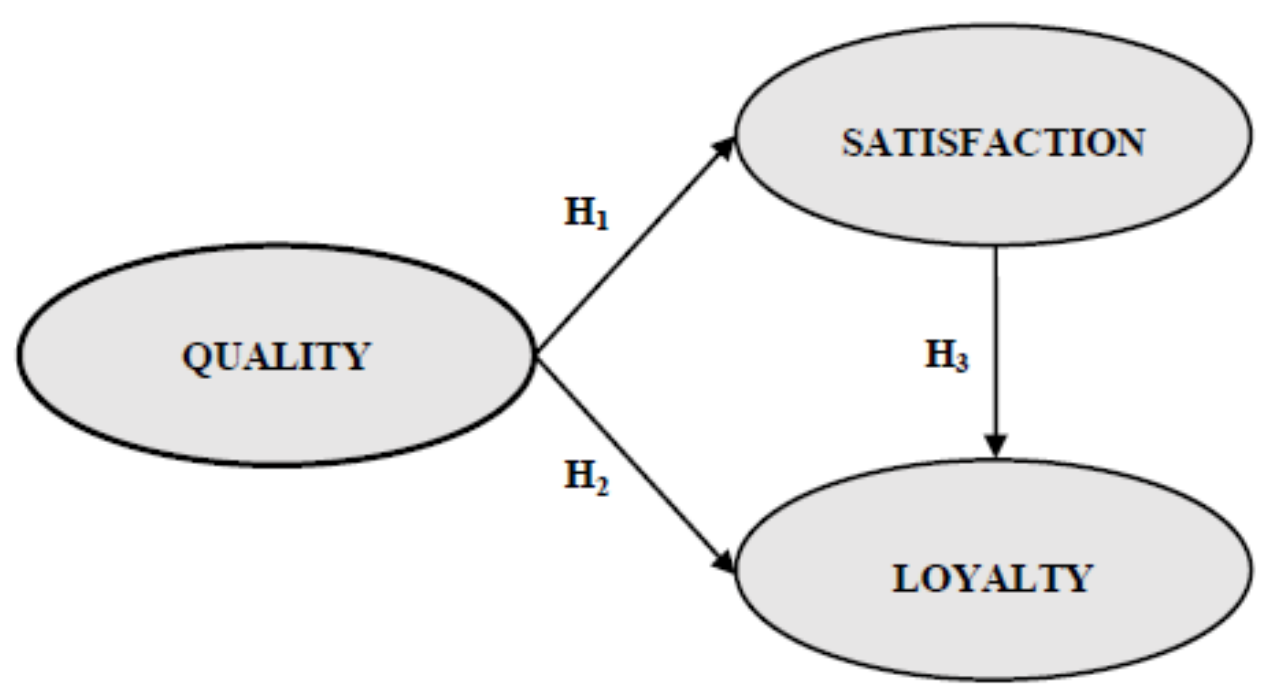

Source: Constructed from a literature review 


\section{Methodology}

\section{Sample and Data Collection}

Primary data were collected with a questionnaire-based survey method. The survey was conducted at the beginning of 2020, which was distributed via the social networks Facebook and Twitter, as well as on the official profile of the Western Serbia Tourism Organization, using the non-probability sampling method, i.e. the convenience sample. The sample has 299 respondents. According to the sample male are most of the respondents (169 respondents). When it comes to education, the respondents are generally highly educated, given that the majority of respondents $(43.5 \%)$ belong to the category of college and university education. Postgraduate studies have $30.8 \%$ of respodents, $24.1 \%$ secondary school and $1.7 \%$ primary school. About half of the respondents $42.1 \%$ are between 25 and 44 years old. The largest number of respondents are from the Belgrade region (36.5\%), 28\% from regions of South and East Serbia and $26.8 \%$ from Vojvodina. The smallest number of respondents came from the Šumadija region and Western Serbia (6\%) and $2.7 \%$ are from a foreign country.

\section{Variables and Measurement}

The RURALQUAL model is developed by Lourerio (2006). This model was used to measure the perceived rural tourism service quality. Evaluation of service quality is based on the opservation of the service actually provided or experienced (Kang, 2006). Respondents rated perceived service quality based on 22 questions (see appendix 1). 4 questions were used to measure tourists 'satisfaction (Loureiro \& González, 2008), while tourists' loyalty was measured through 3 questions (Kim \& Lee, 2018; Pan et al., 2017) (see appendix 1). Responses were measured using a five-point Likert scale (from strongly disagree to strongly agree). SEM analysis was used to test the link between service quality, satisfaction and loyalty of tourists in rural tourism of Šumadija and Western Serbia and to test the hypotheses. Cronbach's alpha values range from 0 to 1 , with values greater than 0.7 being considered to indicate adequate reliability. The results presented in the table below show good reliability and very good reliability.

Table 1. Cronbach's alpha analysis

\begin{tabular}{|l|c|}
\hline \multicolumn{1}{|c|}{ Latent variables } & $\boldsymbol{\alpha}$ \\
\hline Quality & 0.938 \\
\hline Satisfaction & 0.941 \\
\hline Loyalty & 0.883 \\
\hline
\end{tabular}

Source: Calculation based on SPSS 21.0. 


\section{Results and discussions}

\section{Model specification}

The input to the analysis were original data, and for the evaluation of the model parameters was used AMOS v.21. The initial model showed poor performance, so its specification was performed. On this occasion, particular care was taken not to change the theoretical assumptions, but only to obtain better model measures. No new latent variables were added nor were the relationships among them that were theoretically based deleted on model respecification, on the contrary, the model suggested parameters based on the values of the modification indicator and the matrix. The final model is demonstratived in the following figure.

Figure 2. Final research model with results

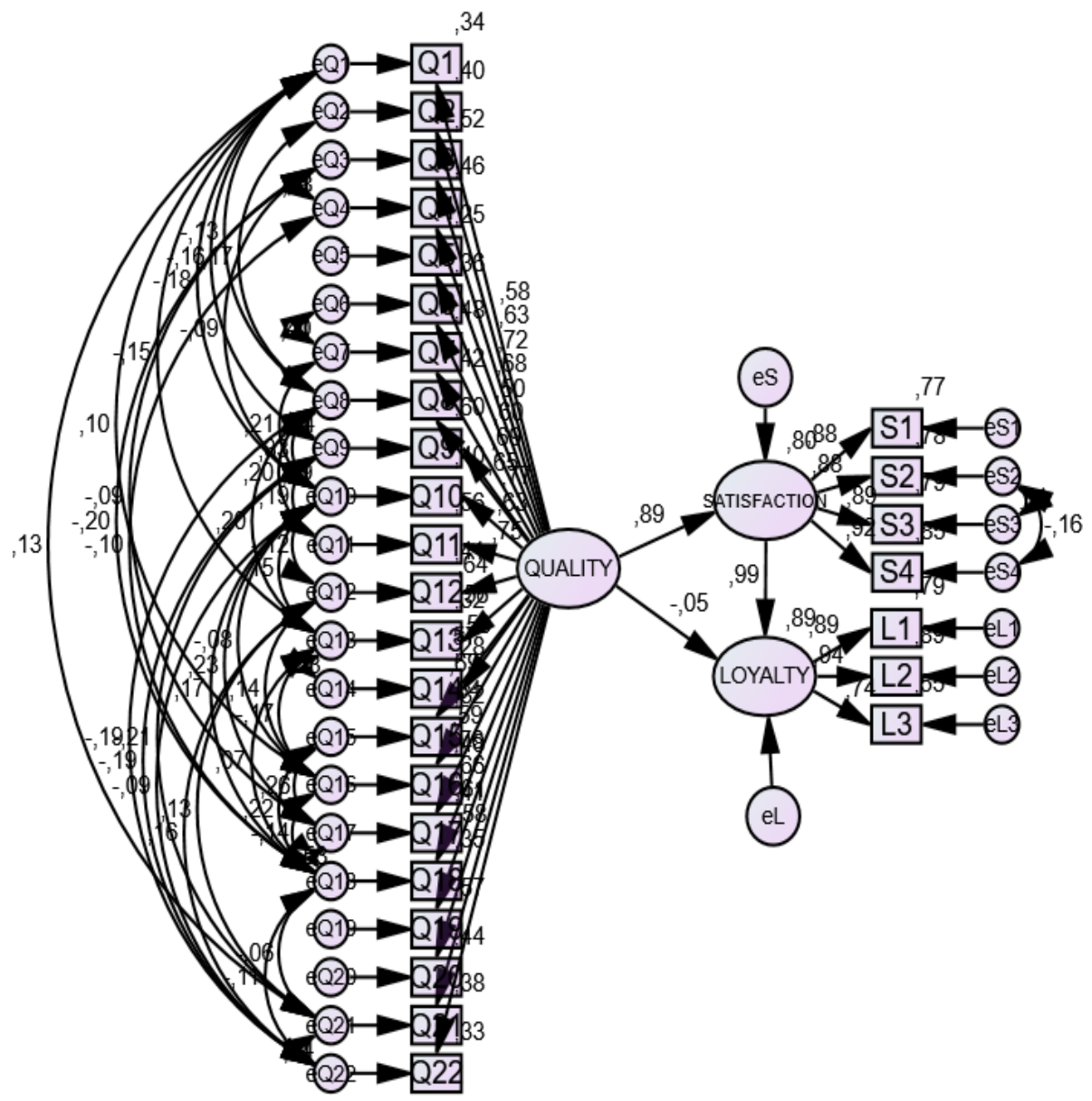

Source: Constructed based on AMOS v.21 


\section{Model estimation}

The model measures were evaluated based on the $\chi^{2}$ test and the RMSEA indicator and its $90 \%$ confidence interval, CMIN / df and CFI. A model is acceptable if the values of these indicators are within the following limits (Brown, 2015; Kline, 2016): $\chi^{2}-$ should be insignificant, ie. $\mathrm{p}>0.05$ RMSEA $\leq 0.08$; $90 \%$ CI RMSEA $\leq 0.08$; CMIN / DF between 1 and 3; CFI $(\geq 0.90)$. The following indicator values were obtained: $\chi 2(483)=$ 587.67; $\mathrm{p}=0.00 ;$ RMSEA $=0.051 ; \mathrm{LO} 90=0.044 ; \mathrm{HI} 90=0.058 ; \mathrm{CMIN} / \mathrm{DF}=1.78$; $\mathrm{CFI}=0.957$. From the obtained values it can be seen that the general indicator $\chi^{2}$ is statistically significant, which indicates that the model does not fit. However, with such a large number of degrees of freedom, $\chi 2$ is not reliable, so it is better to rely on other indicators. The RMSEA indicator is below the limit indicating an excellent model $(0.06)$. The same applies to the confidence interval of this indicator, which is completely below the critical value of 0.08 . The CMIN / DF indicator is within the boundaries that indicate a good model and the CFI is above the lower limit of model acceptance. This means that the model fits the population reasonably well. There are no locally problematic sites in the model after respecification (Figure 2). It can be stated that the model reproduces well the original variance/covariance matrix and is acceptable. The following table shows the percentage of explained variance of indicators and statistical significance.

Table 2. Structural model loadings

\begin{tabular}{|c|c|c|c|c|c|c|}
\hline Variables & Loadings & S.E. & low $95 \%$ & high $95 \%$ & $t$-Value & $p$ \\
\hline \multicolumn{7}{|l|}{ Quality } \\
\hline $\mathrm{Q} 1$ & 0.59 & 0.10 & 0.39 & 0.78 & 9.416 & $* * *$ \\
\hline Q2 & 0.63 & 0.13 & 0.38 & 0.89 & 9.311 & *** \\
\hline Q3 & 0.72 & 0.12 & 0.50 & 0.95 & 10.393 & **** \\
\hline Q4 & 0.68 & 0.14 & 0.41 & 0.94 & 9.861 & $* * *$ \\
\hline Q5 & 0.50 & 0.13 & 0.24 & 0.76 & 7.702 & **** \\
\hline Q6 & 0.60 & 0.14 & 0.33 & 0.86 & 8.909 & *** \\
\hline Q7 & 0.69 & 0.15 & 0.40 & 0.99 & 10.022 & $* * *$ \\
\hline Q8 & 0.65 & 0.14 & 0.37 & 0.93 & 9.458 & **** \\
\hline Q9 & 0.77 & 0.16 & 0.47 & 1.08 & 9.92 & **** \\
\hline Q10 & 0.63 & 0.16 & 0.32 & 0.94 & 9.171 & $* * *$ \\
\hline Q11 & 0.75 & 0.13 & 0.49 & 1.01 & 10.581 & **** \\
\hline Q12 & 0.64 & 0.12 & 0.41 & 0.87 & 10.107 & $* * *$ \\
\hline Q13 & 0.56 & 0.16 & 0.25 & 0.88 & 8.455 & **** \\
\hline Q14 & 0.53 & 0.14 & 0.26 & 0.80 & 8.059 & $* * *$ \\
\hline Q15 & 0.57 & 0.14 & 0.30 & 0.84 & 8.611 & $* * *$ \\
\hline Q16 & 0.69 & 0.12 & 0.46 & 0.93 & 10.059 & $* * *$ \\
\hline Q17 & 0.64 & 0.15 & 0.34 & 0.94 & 9.37 & $* * *$ \\
\hline Q18 & 0.59 & 0.16 & 0.29 & 0.89 & 8.537 & $* * *$ \\
\hline Q19 & 0.76 & 0.15 & 0.47 & 1.04 & 10.744 & $* * *$ \\
\hline Q20 & 0.67 & 0.13 & 0.40 & 0.93 & 9.744 & $* * *$ \\
\hline Q21 & 0.61 & & & & & **** \\
\hline Q22 & 0.74 & 0.09 & 0.39 & 0.76 & 10.646 & *** \\
\hline \multicolumn{7}{|l|}{ Satisfaction } \\
\hline
\end{tabular}




\begin{tabular}{|c|c|c|c|c|c|c|}
\hline Variables & Loadings & S.E. & low 95\% & high 95\% & $\boldsymbol{t}$-Value & $\boldsymbol{p}$ \\
\hline S1 & 0.88 & & & & & ${ }^{* * *}$ \\
\hline S2 & 0.89 & 0.05 & 0.78 & 0.99 & 21.642 & ${ }^{* * *}$ \\
\hline S3 & 0.89 & 0.05 & 0.79 & 0.99 & 22.235 & ${ }^{* * *}$ \\
\hline S4 & 0.92 & 0.05 & 0.83 & 1.01 & 23.771 & ${ }^{* * *}$ \\
\hline Loyalty & & & & ${ }^{* * *}$ \\
\hline L1 & 0.89 & 0.04 & 0.86 & 1.02 & 25.916 & ${ }^{* * *}$ \\
\hline L2 & 0.94 & 0.06 & 0.62 & 0.86 & 16.131 & ${ }^{* * *}$ \\
\hline L3 & 0.74 & 0.06
\end{tabular}

Source: Calculation based on Amos v.21

The previous table shows that all indicators are statistically significant $(* * * \mathrm{p}<.001)$. The existence of a method effect on identifiers affected by the latent quality variable was identified. This effect is small, so it has not been further explored.

The following table shows the results of testing the hypotheses, i.e. the significance of the path.

Table 3. Hypothesis testing results

\begin{tabular}{|l|c|c|c|}
\hline \multicolumn{1}{|c|}{$\begin{array}{c}\text { Hypothesized path } \\
\text { (from } \rightarrow \text { to) }\end{array}$} & $\begin{array}{c}\text { Standardized path } \\
\text { coefficients }\end{array}$ & t-Value & Hypothesis test \\
\hline $\mathrm{H}_{1}:$ Quality $\rightarrow$ Satisfaction & 0.893 & 11,141 & Supported \\
\hline $\mathrm{H}_{2}:$ Quality $\rightarrow$ Loyalty & -0.050 & $-0,571$ & Not Supported \\
\hline $\mathrm{H}_{3}:$ Satisfaction $\rightarrow$ Loyalty & 0.987 & 10,294 & Supported \\
\hline
\end{tabular}

Source: Calculation based on Amos v.21

Based on the obtained results, hypotheses $\mathrm{H} 1$ and $\mathrm{H} 3$ are accepted, while hypothesis $\mathrm{H} 2$ cannot be accepted. The results shows that the Quality $\rightarrow$ Loyalty path is not statistically significant, while the other paths are. This result coincides with similar research in the field of rural tourism (Su \& Fan, 2011; Loureiro \& González, 2008). An additional analysis was made by removing the path from satisfaction to loyalty in the model. In this case, the direct effect of the quality of services on the loyalty of tourists in rural tourism of Sumadija and Western Serbia has been identified $(\beta=0.899 ; p<0.001)$, which means that satisfaction is a mediating variable between quality and loyalty. The direct impact of quality on tourist satisfaction is relatively strong, statistically significant (0.893) and this is moving in a theoretically determined direction, while the link among tourists' satisfaction and their loyalty is very strong and statistically significant (0.893), that is moving in the direction hypothetically presented. The results obtained are in agreement with similar research in this area (Rajaratnam et al., 2014; Osman \& Sentosa, 2013; Loureiro \& González, 2008).

\section{Conclusion}

In recent years, rural tourism has recorded a constant rate of increase in tourist demand and has influenced the development of rural areas through their conservation, stopping the displacement of people from rural areas, creating opportunities to generate income from tourism services and strengthening local agriculture. 
Rural tourism destinations are increasingly dependent on quality. Service quality is vital element of rural tourism households, given that quality as an assessment of standards related to the process of consuming services, and in relation to experience gained, is a significant predictor of satisfaction that further leads to loyalty.

This research investigates the effect of service quality on tourists'satisfaction and loyalty in rural tourism of Šmadija and Western Serbia. Based on the results obtained, the conclusion is that there is a direct influence of service quality on satisfaction, as well as the influence of satisfaction on the loyalty of tourists in rural tourism of Sumadija and Western Serbia. However, research findings did not confirm the direct effect of service quality on loyalty, with quality indirectly affecting guest loyalty through satisfaction. Accordingly, it can be concluded that there is mediation, that is, satisfaction is a mediating variable in the link among the service quality and the tourists' loyalty.

As the quality of services directly affects the tourists' satisfaction and indirectly their loyalty, measuring the service quality in rural tourism of Šumadija and Western Serbia and its continuous improvement are important for the business of rural lodging.

The survey conducted may also have implications for other rural tourism destinations, given that the RURALQUAL model developed by Lourerio (2006) was used to measure service quality, which can assist rural lodging as well as destination management in receiving feedback of provided service quality, in order to introduce an appropriate strategy for improving service quality, and as a consequence tourists will be satisfied with the quality of the service, which further leads to loyalty and profitability.

This research identifies certain limitations that offer the basis for some future research. For future research, the proposed model can be prolonged to other latent variables, such as image, which is an essential element for satisfaction and loyalty of tourists. Also, can be researched the impact of demographic characteristics (domestic and foreign tourists), on the link between service quality, satisfaction and loyalty of tourists.

\section{Conflict of interests}

The authors declare no conflict of interest.

\section{References}

1. Bigović, M.(2016). The effect of quality and satisfaction on customer loyalty: modelling at the tourist destination level. Ekonomske ideje i praksa, (21), 99-112. [in Serbian: Bigović, M. (2016). Uticaj kvaliteta i satisfakcije na lojalnost potrošača: modeliranje na nivou turističke destinacije].

2. Blažević, M., Petres, G., \& Chan, G. (2018). Developing rural tourism in minority ethnic villages: Zlot and Xiaocang She Ethnic Township. Hotel and Tourism Management, 6(2), 71-78. https://doi.org/10.5937/menhottur1802079B

3. Brown, T. A. (2015). Confirmatory factor analysis for applied research. Guilford publications. 
4. Casidy, R. (2014). Linking brand orientation with service quality, satisfaction, and positive word-of-mouth: Evidence from the higher education sector. Journal of Nonprofit \& Public Sector Marketing, 26(2), 142-161. https://doi.org/10.1080/10495 142.2014.901004

5. Cizler, J. (2013). Opportunities for the sustainable development of rural areas in Serbia. Problemy Ekorozwoju, 8(2), 85-91. doi: 10.5937/ekonhor1303229R

6. Chen, C. F., \& Tsai, D. (2007). How destination image and evaluative factors affect behavioral intentions?. Tourism management, 28(4), 1115-1122. https://doi. org/10.1016/j.tourman.2006.07.007

7. Chen, C. F., \& Kao, Y. L. (2010). Relationships between process quality, outcome quality, satisfaction, and behavioural intentions for online travel agencies-evidence from Taiwan. The Service Industries Journal, 30(12), 2081-2092. https://doi. org/10.1080/02642060903191108

8. Chi, X., Lee, S. K., Ahn, Y. J., \& Kiatkawsin, K. (2020). Tourist-perceived quality and loyalty intentions towards rural tourism in China. Sustainability, 12(9), 3614. https:// doi.org/10.3390/su12093614

9. Chuang, S. T. (2010). Rural tourism: Perspectives from social exchange theory. Social Behavior and Personality, 38(10), 1313. https://doi.org/10.2224/sbp.2010.38.10.1313

10. Cronin Jr, J. J., \& Taylor, S. A. (1992). Measuring service quality: a reexamination and extension. Journal of marketing, 56(3), 55-68. https://doi. org/10.1177/002224299205600304

11. Cronin Jr, J. J., \& Taylor, S. A. (1994). SERVPERF versus SERVQUAL: reconciling performance-based and perceptions-minus-expectations measurement of service quality. Journal of marketing, 58(1), 125-131. https://doi. org/10.1177/002224299405800110

12. Cvijanović, D. V., \& Mihailović, B. (2016). Developmental aspects of the Rural Tourism in Serbia. In D. Cvijanović (Ed.), Thematic Proceedings $1^{\text {st }}$ International Scientific Conference Tourism in Function of Development of the Republic of Serbia: Spa tourism in Serbia and experiences of other countries (1-16). University of Kragujevac, Faculty of Hotel Management and Tourism in Vrnjačka Banja.

13. Dašić, D., Živković, D., \& Vujić, T. (2020). Rural tourism in development function of rural areas in Serbia. Economics of Agriculture, 67(3), 719-733. doi:10.5937/ ekoPolj2003719D

14. Demonja, D., \& Ružić, P. (2010). Ruralni turizam u Hrvatskoj: s hrvatskim primjerima dobre prakse i europskim iskustvima. Meridijani.

15. Fang, W. T. (2020). Rural Tourism. In Tourism in Emerging Economies (pp. 103-129). Springer, Singapore. https://doi.org/10.1007/978-981-15-2463-9

16. Gašić, M. (2016). Tourism as a development factor of rural areas in Southren and Eastern Serbia. Doctoral dissertation, Faculty of Economics, Niš. [in Serbian: Gašić, M. (2016). Turizam u funkciji razvoja ruralnih područja južne i istočne Srbije]. 
17. Gašić, M., Perić, G., \& Ivanović, V. (2015a). Development of rural tourism in the Republic of Serbia. BizInfo (Blace), 6(2), 71-81. [in Serbian: Gašić, M., Perić, G., \& Ivanović, V. (2015a). Razvijenost ruralnog turizma u Republici Srbiji]. https://doi. org/10.5937/BIZINFO1502071G

18. Gašić, M., Perić, G., Ivanović, V., \& Oklobžija, S. (2015b). Quality mangement in rural tourist areas. 18. International Conference ICDQM-2015, Prijedor, 152-158. [in Serbian: Gašić, M., Perić, G., Ivanović, V., \& Oklobžija, S. (2015b). Upravljanje kvalitetom ruralnih turističkih područja].

19. Giese, J. L., \& Cote, J.A. (2000). Defining consumer satisfaction. Academy of marketing science review, 1(1), 1-22.

20. Grubor, A., \& Milićević, N. M. (2019). The implementation of hierarchical latent models in the measurement of perceived service quality. Marketing, 50(3), 179-185. https://doi.org/10.5937/markt1903179G

21. Grönroos, C. (1984). A service quality model and its marketing implications. European Journal of marketing, 18(4), 36-44. https://doi.org/10.1108/EUM0000000004784

22. He, Y., \& Song, H. (2009). A mediation model of tourists' repurchase intentions for packaged tour services. Journal of Travel Research, 47(3), 317-331. https://doi. org/10.1177/0047287508321206

23. Hennessey, S. M., Yun, D., MacEachern, M. \& MacDonald, R. (2007). An examination of the effects of perceived quality, price-value and satisfaction on golf tourists' behavioural intentions: a structural model. Travel and Tourism Research Association (TTRA) Annual Conference, Canada, 1-12.

24. Heung, V. C., \& Cheng, E. (2000). Assessing tourists' satisfaction with shopping in the Hong Kong special administrative region of China. Journal of Travel Research, 38(4), 396-404. https://doi.org/10.1177/004728750003800408

25. Hosany, S., Ekinci, Y., \& Uysal, M. (2006). Destination image and destination personality: An application of branding theories to tourism places. Journal of business research, 59(5), 638-642. https://doi.org/10.1016/j.jbusres.2006.01.001

26. Hu, H. H., Kandampully, J., \& Juwaheer, T. D. (2009). Relationships and impacts of service quality, perceived value, customer satisfaction, and image: an empirical study. The service industries journal, 29(2), 111-125. https://doi.org/10.1080/02642060802292932

27. Irz, X., Lin, L., Thirtle, C., \& Wiggins, S. (2001). Agricultural productivity growth and poverty alleviation. Development policy review, 19(4), 449-466. https://doi. org/10.1111/1467-7679.00144

28. Jurdana, D. S., \& Frleta, D. S. (2012). Tourism development of rural areas-customer perspective. $6^{\text {th }}$ International Conference of the School of Economics and Business , Beyond the Economic Crisis: lessons Learned and Challenges Ahead”, Sarajevo, 191-205.

29. Kang, G. D. (2006). The hierarchical structure of service quality: integration of technical and functional quality. Managing Service Quality: An International Journal, 16(1), 37 50. https://doi.org/10.1108/09604520610639955 
30. Kim, H. K., \& Lee, T. J. (2018). Brand equity of a tourist destination. Sustainability, 10(2), 431. https://doi.org/10.3390/su10020431

31. Kline, R.B.(2016). Principles and practice of structural equationmodeling. Guilford publications.

32. Koster, R. L., \& Lemelin, R. H. (2009). Appreciative inquiry and rural tourism: a case study from Canada. Tourism Geographies, 11(2), 256-269. https://doi. org/10.1080/14616680902827209

33. Kozak, M., \& Beaman, J. (2006). Relationship between satisfaction and future behavior. Tourism Analysis, 11(6),397-409.https://doi.org/10.3727/108354206781040795

34. Lane, B. (1994). What is rural tourism?. Journal of sustainable tourism, 2(1-2), 7-21. https://doi.org/10.1080/09669589409510680

35. Lee, B. C., \& Kim, D. K. (2009). Relative importance to tourism decision makers of indicators for sustainable rural tourism development in South Korea: Using AHP approach. Journal of Tourism, 10(2), 21-43.

36. Lee, S., Jeon, S., \& Kim, D. (2011). The impact of tour quality and tourist satisfaction on tourist loyalty: The case of Chinese tourists in Korea. Tourism Management, 32(5), 1115-1124. https://doi.org/10.1016/j.tourman.2010.09.016

37. Loureiro, S. M. C. (2012). Tourism in rural areas: foundation, quality and experience. Visions for Global Tourism Industry-Creating and Sustaining Competitive Strategies, S1, InTech, 441-460.

38. Loureiro, S. M. C., \& González, F. J. M. (2008). The importance of quality, satisfaction, trust, and image in relation to rural tourist loyalty. Journal of Travel \& Tourism Marketing, 25(2), 117-136. https://doi.org/10.1080/10548400802402321

39. Loureiro, S. M. C. (2006). Gestión de la Calidad en el Turismo Rural. PhD dissertation. Universidad Extremadura, Spain.

40. Loureiro, S. M. C., \& González, F. J. M. (2009). Perceived quality in rural lodgings in Spain and Portugal: the RURALQUAL scale. Portuguese Journal of Management Studies, 14(1), 33-52.

41. Loureiro, S. M. C., \& Kastenholz, E. (2011). Corporate reputation, satisfaction, delight, and loyalty towards rural lodging units in Portugal. International Journal of Hospitality Management, 30(3), 575-583. https://doi.org/10.1016/j.ijhm.2010.10.007

42. Maestro, R. M. H., Gallego, P. A. M., \& Requejo, L. S. (2007). The moderating role of familiarity in rural tourism in Spain. Tourism Management, 28(4), 951-964. https://doi. org/10.1016/j.tourman.2006.08.009

43. Mandarić, M., Milicević, S., \& Sekulić, D. (2017). Traditional values in the function of promotion of Šumadija and Pomoravlje as rural tourism destinations. Economics of Agriculture, 64(2), 787-803. https://doi.org/10.5937/ekoPolj1702787M

44. Martínez, J. M. G., Martín, J. M. M., Fernández, J. A. S., \& Mogorrón-Guerrero, H. (2019). An analysis of the stability of rural tourism as a desired condition for sustainable tourism. Journal of Business Research, 100, 165-174. https://doi.org/10.1016/j. jbusres.2019.03.033 
45. Milićević, S., Podovac, M., \& Čavlin, M. (2015). Resources for development of the Rača Municipality as a rural tourism destination. Economics of Agriculture, 62(3), 751765. https://doi.org/10.5937/ekoPolj1503751M

46. Novaković, S., \& Perić, G. (2018). The identification of the main factors of the development of rural tourism on Stara Planina mountain. $3^{\text {rd }}$ International Thematic Monograph Thematic Proceedings: Modern Management Tools and Economy of Tourism Sector in Present Era, Belgrade, 775-786. https://doi.org/10.31410/tmt.2018.775

47. Nowacki, M. M. (2009). Quality of visitor attractions, satisfaction, benefits and behavioural intentions of visitors: Verification of a model. International Journal of Tourism Research, 11(3), 297-309. https://doi.org/10.1002/jtr.689

48. Osman, Z., \& Sentosa, I. (2013). Mediating effect of customer satisfaction on service quality and customer loyalty relationship in Malaysian rural tourism. International Journal of Economics Business and Management Studies, 2(1), 25-37.

49. Pan, L., Zhang, M., Gursoy, D., \& Lu, L. (2017). Development and validation of a destination personality scale for mainland Chinese travelers. Tourism Management, 59, 338-348. https://doi.org/10.1016/j.tourman.2016.08.005

50. Parasuraman, A., Zeithaml, V. A., \& Berry, L. L. (1985). A conceptual model of service quality and its implications for future research. Journal of marketing, 49(4), 41-50. https://doi.org/10.1177/002224298504900403

51. Parasuraman, A., Zeithaml, V. A., \& Berry, L. L. (1988). Servqual: A multiple-item scale for measuring consumer perception of service quality. Journal of retailing, 64(1), 12-40.

52. Perić, G., Gašić, M., Stojiljković, M., \& Nešić, I. (2018). The impact of employee satisfaction on the tourist satisfaction with the services of spa tourism. Economics of Agriculture, 65(2), 617-632. https://doi.org/10.5937/ekoPolj1802617P

53. Pavlović, N. (2016). Entrepreneurial idea as a chance for rural tourism development. In D. Cvijanović (Ed.), Thematic Proceedings $1^{\text {st }}$ International Scientific Conference Tourism in Function of Development of the Republic of Serbia: Spa tourism in Serbia and experiences of other countries (552-568). University of Kragujevac, Faculty of Hotel Management and Tourism in Vrnjačka Banja.

54. Petrick, J. F. (2004). The roles of quality, value, and satisfaction in predicting cruise passengers' behavioral intentions. Journal of travel research, 42(4), 397-407. https:// doi.org/10.1177/0047287504263037

55. Perić, G., Dramićanin, S., \& Milenkovski, A. (2020). Measuring perception of service quality of Serbian rural tourism using RURALQUAL scale. Bizinfo (Blace), 11(1), 1-17. https://doi.org/10.5937/bizinfo2001001P

56. Pike, S. (2009). Destination brand positions of a competitive set of near-home destinations. Tourism management, 30(6), 857-866. https://doi.org/10.1016/j. tourman.2008.12.007

57. Podovac, M., Đorđević, N., \& Milićević, S. (2019). Rural tourism in the function of life quality improvement of rural population on Goč mountain. Economics of agriculture, 66(1), 205-220. https://doi.org/10.5937/ekoPolj1901205P 
58. Radović, G. (2013). Problems of development of rural tourism in the Republic of Serbia. Agroekonomika, 59-60, 114-123. [in Serbian: Radović, G. (2013). Problemi razvoja ruralnog turizma u Republici Srbiji].

59. Rajaratnam, S. D., Munikrishnan, U. T., Sharif, S. P., \& Nair, V. (2014). Service quality and previous experience as a moderator in determining tourists' satisfaction with rural tourism destinations in Malaysia: A partial least squares approach. Procedia-Social and Behavioral Sciences, 144(144), 203-211. https://doi.org/10.1016/j.sbspro.2014.07.288

60. Roberts, L., \& Hall, D. (2001). Rural tourism and recreation: Principles to Practise. CABI Publishing. http://doi.org/10.1079/9780851995403.0000

61. Sharpley, R. (2002). Rural tourism and the challenge of tourism diversification: the case of Cyprus. Tourism management, 23(3), 233-244. https://doi.org/10.1016/S02615177(01)00078-4

62. Simonović, Z., \& Ćurčić, N. V. (2020). Problems of Marketing Rural Tourism in Serbia. In Handbook of Research on Agricultural Policy, Rural Development, and Entrepreneurship in Contemporary Economies (pp. 296-313). IGI Global. doi: 10.4018/978-1-5225-9837-4.ch015

63. Singh, J. (1991). Understanding the structure of consumers' satisfaction evaluations of service delivery. Journal of the academy of marketing science, 19(3), 223-244.

64. Statistical Office of the Republic of Serbia, Statistical Yearbook 2019, https://www.stat. gov.rs/en-us/publikacije/ (16 January 2020).

65. Su, L., \& Fan, X. (2011). A study on the relationships between service quality, satisfaction, trust and loyalty among rural tourism. In ICSSSM11 (pp. 1-6). IEEE. https://doi.org/10.1109/ICSSSM.2011.5959418

66. Su, L., Swanson, S.R. and Chen, X. (2016), The effects of perceived service quality on repurchase intentions and subjective well-being of Chinese tourists: the mediating role of relationship quality, Tourism Management, 52, pp. 82-95. doi: 10.1108/SJME-09-2018-0041

67. Topalović, S., \& Marinković, V. (2020). A multidimensional approach to the analysis of perceived value in tourism. Hotel and Tourism Management, 8(1), 49-58. https://doi. org/10.5937/menhottur2001049T

68. Tsiotsou, R. (2006). The role of perceived product quality and overall satisfaction on purchase intentions. International journal of consumer studies, 30(2), 207-217. https:// doi.org/10.1111/j.1470-6431.2005.00477.x

69. UNWTO, Master plan - Sustainable Tourism for Rural Development, https:// futurehospitalityleaders.files.wordpress.com/2012/11/master-plan-odrzivog-razvojaruralnog-turizma-u-srbiji.pdf (16 January 2020)

70. Veljković, S., \& Đorđević, A. (2010). Brand values for consumers and companies. Marketing, 41(1), 3-16. [in Serbian: Veljković, S., \& Đorđević, A. (2010). Vrednost brenda za potrošače i preduzeća].

71. Vujić, M., Đorđević, S., \& Lakićević, M. (2019). Service quality and customer satisfaction in the hotel industry in Serbia. Hotel and Tourism Management, 2019, 7(1), 61-70. https://doi.org/10.5937/menhottur1901061V 
72. Vuković, P. (2017). Karakter i dinamika razvoja ruralnog turizma u Republici Srbiji. Ekonomika, 63(4), 53-60. Doi:10.5937/ekonomika1704053V

73. Wang, C. Y., \& Hsu, M. K. (2010). The relationships of destination image, satisfaction, and behavioral intentions: An integrated model. Journal of Travel \& Tourism Marketing, 27(8), 829-843. https://doi.org/10.1080/10548408.2010.527249

74. Xue, L., \& Kerstetter, D. (2019). Rural tourism and livelihood change: An emic perspective. Journal of hospitality \& tourism research, 43(3), 416-437. https://doi. org/10.1177/1096348018807289

75. Žabkar, V., Brenčič, M. M., \& Dmitrović, T. (2010). Modelling perceived quality, visitor satisfaction and behavioural intentions at the destination level. Tourism management, 31(4), 537-546. https://doi.org/10.1016/j.tourman.2009.06.005

Appendix 1 Measurement items of quality, satisfaction and loyalty

\begin{tabular}{|c|l|}
\hline Q1 & The rural households food is well presented and tasteful. \\
\hline Q2 & The rural households employees have a clean and tidy appearance. \\
\hline Q3 & The clients are treated warmly and kindly. \\
\hline Q4 & A personalized care is provided to each guest. \\
\hline Q5 & The arrival schedules are determined, but they are quite flexible. \\
\hline Q6 & The reservations of rooms are easily performed. \\
\hline Q7 & $\begin{array}{l}\text { The reservations are confirmed on the easiest way for guest, other informations of interest are } \\
\text { sent also. }\end{array}$ \\
\hline Q8 & The rural households facilities are in good condition. \\
\hline Q9 & The rural households facilities and rooms have cozy furniture. \\
\hline Q10 & The rural household is well acclimated. \\
\hline Q11 & The rural household facilities and rooms are clean. \\
\hline Q12 & The decoration materials and objects are from local tradition. \\
\hline Q13 & The rural household access is easy. \\
\hline Q14 & The household offers easy parking. \\
\hline Q15 & The guests are included in rural life of region. \\
\hline Q16 & The typical region gastronomy is included on household menu. \\
\hline Q17 & The access to cultural, recreation, and/or sport activities is enabled. \\
\hline Q18 & Fairs, special parties and other aspects of cultural interest exist in the region enviroment. \\
\hline Q19 & The household employees know the job they are doing. \\
\hline Q20 & The household architecture has a style of a region. \\
\hline Q21 & The place where household is located has a beautiful natural prettiness. \\
\hline Q22 & The household is located in a peaceful place. \\
\hline S1 & I am satisfied with my stay in the rural household. \\
\hline S2 & The rural household provided the service I looked for. \\
\hline S3 & I am pleased with the services delivered by the rural household. \\
\hline S4 & In general, my experience is very positive. \\
\hline L1 & I will visit this rural household again. \\
\hline L2 & I will be happy to recommend this rural household to relatives and friends.. \\
\hline L3 & I will visit this rural household in case of increased service prices. \\
\hline
\end{tabular}

Source: Kim \& Lee, 2018; Pan et al., 2017; Loureiro \& González, 2008. 